\begin{tabular}{llrr} 
A C T A II C H T H Y O L O G I C A & E T & P I S C A T O R I A \\
Vol. XX Fasc. 2 & & Szczecin, 1990 \\
\hline
\end{tabular}

Mohamed Hassan MOURAD

Fish physiology

\title{
EFFECTS OF LINDANE ON THE ELECTROCARDIOGRAM OF
}

EEL, ANGUILLA ANGUILLA L.

\section{WPEYW LINDANU NA ZMIANY ELEKTROKARDIOGRAMU U WĘGORZA ANGUILLA ANGUILLA L.}

Institute of Ichthyology, Dept. of Fish Physiology, Szczecin

Electrocardiogram were measured in eel exposed to lindane. The character of the ECG's obtained points out to a considerable damage in the cardiac muscle. The most important diagnostic feature of these ECG's changes are, disturbances in the ionic equilibrium, myocardiac infarction and ventricular extrasystole.

\section{INTRODUCTION}

The toxicity of pesticides to aquatic organisms is now one of the major problems with which most of marine scientists are concerned. Among the pesticides, lindane, Gamma-isomer of hexachlorocyclohexane. Lindane is very hazardous to aquatic organisms because this chemical is highly toxic, resistant to degradation and easily absorbed by the fish (Gakstatter and Weiss, 1967; Oloffs et al. 1972; Schimmel et al. 1977). Although there have been many reports on the lesion caused by lindane in aquatic organisms, few systematic description of the toxic syndrome associated with exposure to this insecticide have been presented. Such descriptions are clearly desirable as an aid in understanding the mechanisms of lindane action and could have a diagnostic value in the investigation of fish mortality. Therefore, the main objective of this study is to assess the effect of lindane on the electrocardiogram of the eel fish. 


\section{MATERIALS AND METHODS}

Individuals of eel Anguilta anguilla L. weight $213 \pm 73.3 \mathrm{gm}$ and measuring $56.5 \pm 7.6 \mathrm{~cm}$ were brought to the laboratory and acclimated for at least one week urder appropriate experimental conditions. Fish electrocardiogram were obtained with the method of Labat (1966), using a single channel CGK-301 electrocardiographic apparatus and $\mathrm{CMK}-405$ cardiomonitor. Before the electrodes were placed on the fish, the skin was rubbed with a dry cloth to remove the mucus as much as possible as this had been found to have a strong insulating effect. Recording the ECG began after returning the fish with the electrodes to normal conditions at paper speed $25 \mathrm{~mm} / \mathrm{sec}$. A stock solution of the ingredient lindane was prepared in aceton which individually subjected to threshold and lethal doses of lindane in a glass aquarium containing 20 liters of aerated tap-water. The water temperature, $\mathrm{pH}$ and oxygen content ranged within $18-19^{\circ} \mathrm{C}, 7.2-7.8,9.2-8 \mathrm{mg} / 1$ respectively. Changes in the ECG of the fish under the influence of lindane was recorded. Detoxication ability of the eel after a short exposure to lethal dose of lindane was also studied by placing the fish in aerated tap-water free of lindane. Statistical test ,t-test ${ }^{2}$ was made to evaluate the significance changes caused by lindane.

\section{RESULTS}

\section{A. Effects of threshold dose of lindane.}

The preliminary investigations showed that the minimum dose of lindane which is just strong enough to elicit a change in the ECG of the eel was $0.03 \mathrm{mg} / 1$. This concentration has been accepted as a threshold dose in these experiments. Changes in the ECG of the eel after exposure to $0.03 \mathrm{mg} / 1$ lindane for $1 \mathrm{~h}$ are shown in Table 1. It is evident that this dose cause a rise in the $\mathrm{R}$ wave from 0.47 to $0.53 \mathrm{mv}$, , the $\mathrm{T}$ wave from 0.05 to $0.08 \mathrm{mv}$ while the $\mathrm{P}$ wave decreased from 0.03 to $0.02 \mathrm{mv}$., which reflects a distrubances in the electrical potential of the cardiac muscle. The $P-Q, S-T, T-P$ segments were elongated from $0.20,0.57,0.58$ to $0.23,0.62,0.76$ millisecond, as well as the P-Q, Q-T, R-R intervals from $0.30,0.95,1.89$ to $0.34,1.08,2.26$ millisecond respectively. On the other hand, the heart rate of the eel decreased from 37.60 to 31.30 beats/min. Statistically, all these changes were non-significant.

B. Effects of lethal dose of lindane.

Changes in the ECG of the eel after exposure to $0.3 \mathrm{mg} / 1$ lindane are shown in Fig $1^{A}$ a-h. The normal ECG of the eel are illustrated in Fig. 1 a: the waves appeared normal an the heart rate was 46.90 beats $/$ min. Fig. $1^{\mathrm{A}}$ b-c presents the ECG of the eel 

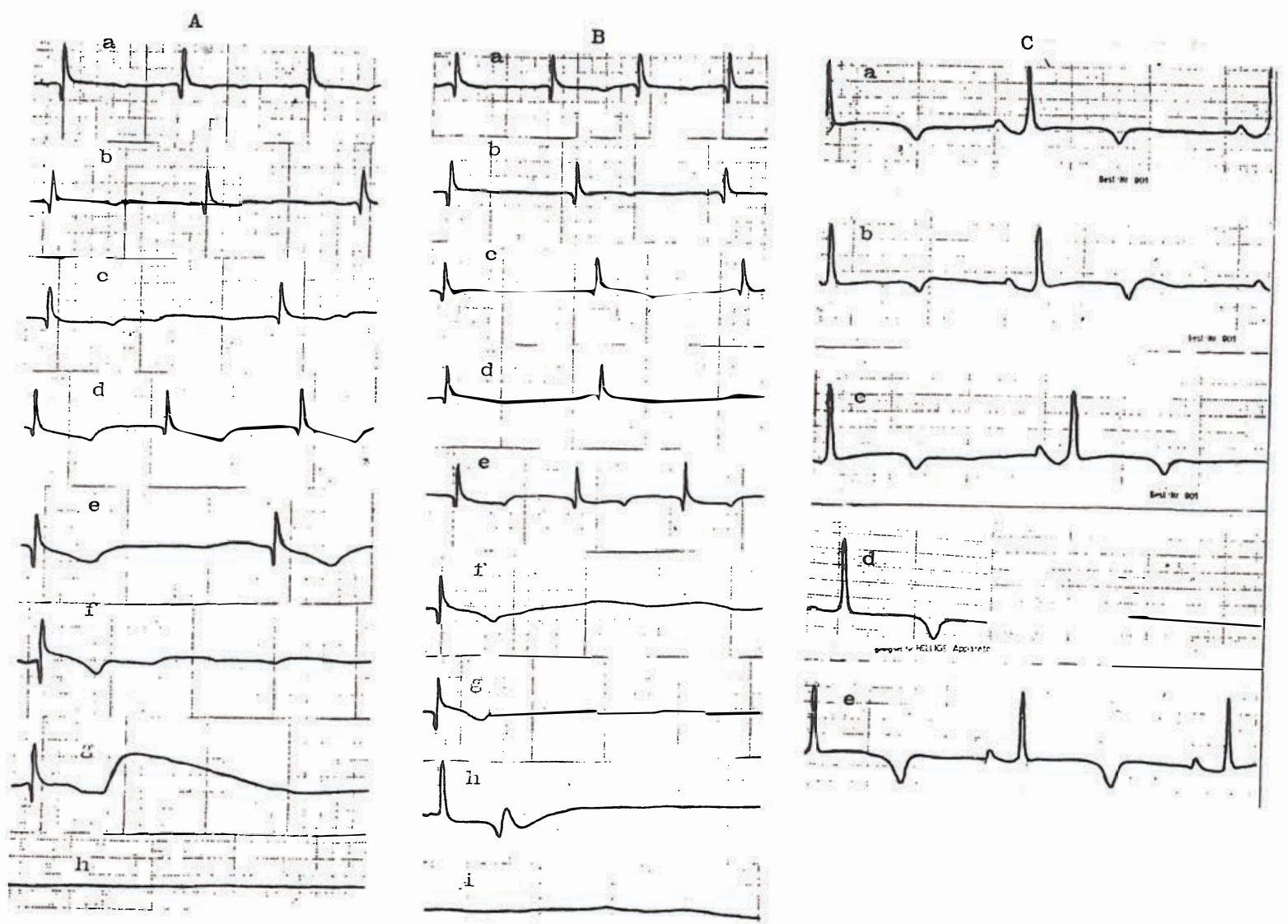

Fig. 1. Changes in the ECG of eel exposed to: A. $0.3 \mathrm{mg} / 1$ lindane, B. $0.6 \mathrm{mg} / 1$ lindane.

C. $1.8 \mathrm{mg} / 1$ lindane and returned to clean water 
during the first one hour of exposure to lindane: the heart rate is slowed down to 36.80 beats/min.; there are a tendency to increase the $T$ wave amplitude and to lower the S-T segment, which reflect disturbed repolarization of the ventricular cardiac muscle. Fig. $1^{\mathrm{A}}$ d shows a decreased heart rate accompained by intensified disturbances in the ventricular cardiac muscle repolarization seen as an obliquely lowered $\mathrm{S}$-T segment and a deep negative $\mathrm{T}$ wave. Fig. $1^{\mathrm{A}}$ e shows a considerable decrease in the heart rate. Statistically, changes in the fish heart rate were significant after $3 \mathrm{~h}$ of exposure to lindane. Moreover, the QRS complex is widened as a reflection of disturbed depolarization of the ventricular cardiac muscle; the deepened and widened $\mathrm{Q}$ wave may evidence patchy nercosis in the ventricular cardiac muscle. Fig. $1^{A}$ f shows a further :" slowed down in the heart beat with persistance disturbances in the depolarization and repolarization of the ventricular cardiac muscle; an undulating depression of the S-T segment may be correspond to the so-called „damage current" in the cardiac muscle. Fig. $1^{\mathrm{A}} \mathrm{h}$ shows a single QRS complex followed by cardiac asystolia. The complete absence of the bioelectric activity was observed after $24 \mathrm{~h}$ of exposing the fish to lindane as shown in Fig. $1^{\mathrm{A}} \mathrm{h}$.

As shown in Fig. $1^{B}$ a-i an increase of lindane concentration from $0.3 \mathrm{mg} / 1$ to $0.6 \mathrm{mg} / 1$ increased the intensity of the above described changes. Fig. 2 a shows the control ECG of the eel: the waves appeared normal; the heart rate was 40.00 beats/min. Fig. $1^{{ }^{B}}$ b-d is the ECG during $45 \mathrm{~min}$. of exposure the fish to the insecticide: the heart rate is slowed down to 35.00 beats/min., with a tendency to lower the previously depressed S-T segment, which may correspond to the so-called ,damage current" of the cardiac muscle; the T wave amplitude increased from 0.05 to $0.11 \mathrm{mv}$. and was flattend. Fig. $1^{B}$ e shows an an acceleration in the heart rate to 39.50 beats/min. after $1 \mathrm{~h}$ of exposing to lindane; a further depression of the S-T segment may be seen as well. Fig. $1^{B}$ f shows a considerable slowed down in the heart rate. Statitically, changes in the heart rate were significant after $90 \mathrm{~min}$. of exposure the eel to lindane. The QRS complex is widened too, which reflects a disturbance in the depolarization of the ventricular cardiac muscle. On the other hand, the S-T segment was lowered and passed into the negative $T$ wave. Fig. $1^{B} \mathrm{~g}$ shows a very pronounced bradycardia; the $\mathrm{Q}$ wave deepened further which may evidence patchy nercosis of the cardiac muscle. Fig. $1^{B}$ g shows two probably additional stimulation „extrasystole" from different center followed by asystolia. The first stimulation is probably superventricular in origin and the second extrasystole is presumbly ventricular in origin, after $14 \mathrm{~h}$ of exposure the fish to lindane the duration of segments and intervals are prolonged leading finally to a complete disappearance ot the bioelectric phenomena as shown in Fig. $1^{B}$ i. 
Table

Changes in the ECG's. heart rate and respiratory rate of the eels after exposure to $0.03 \mathrm{mg} / \mathrm{l}$ lindiane.

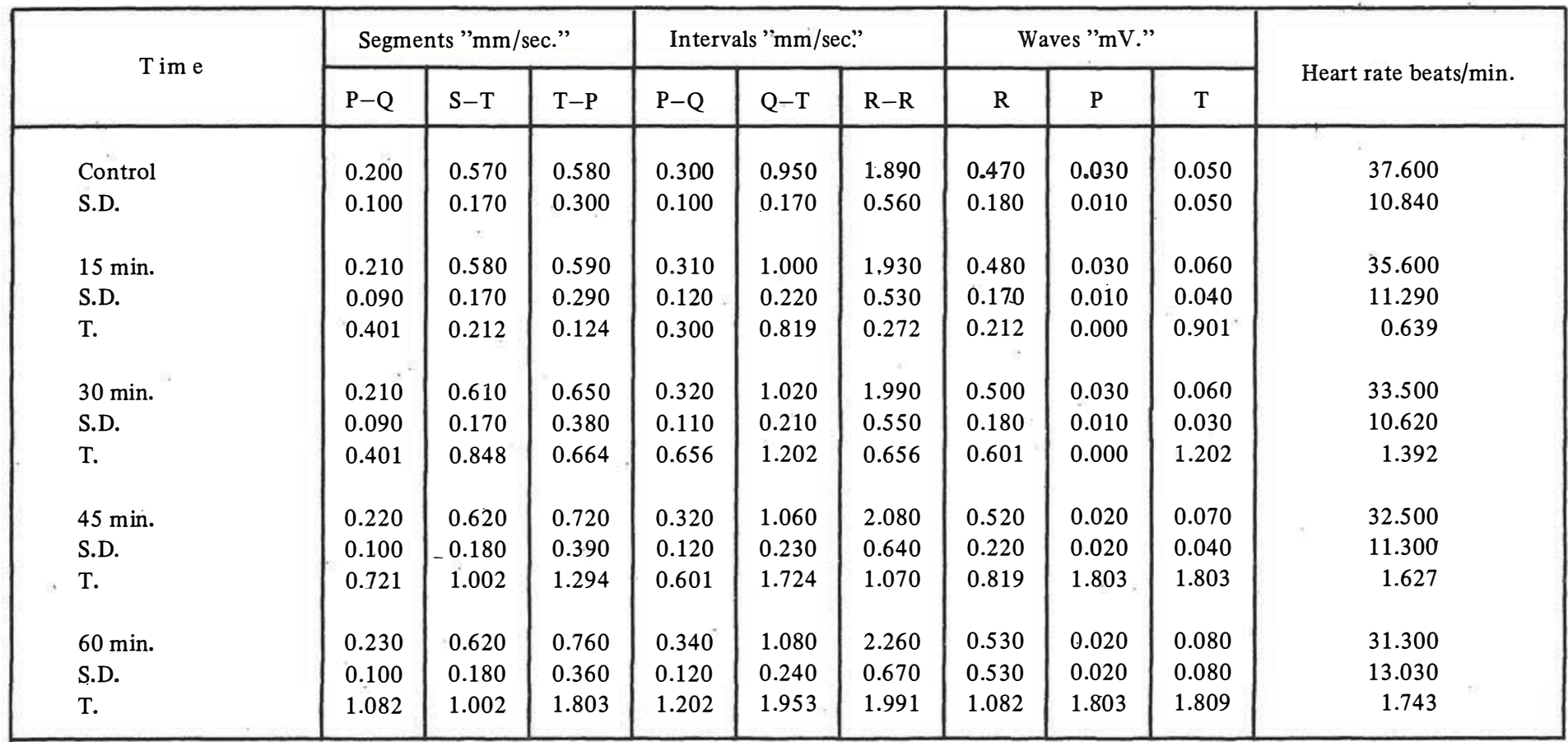

Average of 13 fish

Critical "t" at $5 \%$ level $=2.178$ 


\section{Detoxication ability of the eel}

Detoxication ability of the eel after a short exposure to lethal concentration ${ }_{\text {,5 }} 1.8 \mathrm{mg} / 1$ " lindane are shown in Fig. ${ }^{\mathrm{C}}$ a.e. Fig. 3 a is the control ECG of the eel: the PQRST waves appeared normal; the heart rate was 35.10 beats/min. Fig. $1^{\mathrm{C}} \cdot \mathrm{b}-\mathrm{d}$ shows the ECG of the eel during $15 \mathrm{~min}$. of exposure to lindane: the heart rate slowed down significantly to 18 beats/min.; the $\mathrm{P}$ wave was Hattened, which may be associated with disturbed atrial depolarization; a deepened negative $T$ wave suggests disturbed repolarization of the ventricular cardiac muscle. Placing the eel in aerated tap-water free of lindane results in return the ECG of the fish to their initial values during $15 \mathrm{~min}$. as shown in Fig. $1^{\mathrm{C}}$ e. The differences between the ECG obtained and the control were non-significant. However, the $T$ wave was deeper than the control which may evidence a persistent repolarization disturbance in the ventricular cardiac muscle.

\section{DISCUSSION}

The ECG records obtained from the eel Anguilla anguilla L. was not different from that observed in birds and mammals. The only difference was that the amplitude of waves in the eel ECG's were lower; the duration of segments and intervals being longer. In this study, the fish heart gives a clearly negative chronotropic responce after exposure to a threshold dose of lindane, which is explained as being caused by the depressing action of the vagal nerve/Belaud et al. 1969; Siato, 1973; Holmgren, 1977). Physiologically, bradycaradia has been viewed as an economic attempt on the part of the fish to either bring about a decrease in oxygen expenditure (Heath, 1964), or to facilitate oxygen uptake (Holeton and Randall, 1967). It has also been confirmed that the vagal bradycardia is accompanied by an increase in the electrical action potential at the ventricle with a decrease of the atrial one "P wave". This fact points out to an impairment of internodal conduction with an increase of the diastolic time. The character of the ECG's obtained after exposing the eel to lethal concentrations of lindane points out to a considerable damage in the cardiac muscle. The most important diagnostic feature of these ECG changes are disturbances in the ionic equillbrium. Impairment of the osmoregulatory and electrolytic regulation system are well known in fish exposed to organochlorine pesticides (Janicki and Kinter, 1971; Leadem et al. 1974). Nelson (1982), found that a shift in ionic equilibrium is a further factor in the depression of heart rate. The disturbances in the depolarization and repolarization showed after exposing the eel to lethal doses of lindane suggested that there are an alteration in the heart cations i.e. intracellular $\mathrm{Na}$ accumulation and intracellular $\mathrm{K}$ depletion due to the inhibition of the $\mathrm{Na}^{+}-\mathrm{K}^{+}$ATPase as the effect of 
lindane. This results is an agreement with Yap et al. (1975) and Rao (1986), who demonstrated the inhibitory effects of chlorinated chydrocarbon insecticides on the ATPase activity of the fish. Myocardial infarction was also observed after exposing the eel to lindane. This probably results from a necrosis area in the heart muscle producing a prominent and widened the $Q$ wave as shown in Fig.le and in Fig. 2g. Prominent and widened of $Q$ wave may be due to the fact that the dead tissue present an open window to the electrodes which is now electrically directly in the cavity of the heart (Rollason, 1966). Zone of injury which is just followed the zone of nercosis causes the $\mathrm{S}$-T segment to be elevated or depressed depending to the position of the electrode with respect to the zone of injury (Schamrotch, 1966). In this study, ventricular extrasystole was also observed. This probably results from stimulation of the ventricle during diastole after its refractory period has passed. On the other hand, it was found that placing the eel in aerated tap-water free of lindane after a short exposure to lethal dose demonstrated a considerable detoxication ability since after about 15 min. the ECG of the fish returned to normal except for a slightly widened and deepened the $T$ wave, which reflect a slight disturbance in the ventricular cardiac muscle repolarization. This rapid normalization was probably due to the fact that the eel lives in two different aquatic environments and tolerates a considerable differences in ionic composition during migration.

\section{CONCLUSIONS}

1. The fish heart of the eel gives a clearly negative chronotropic response after exposure to lindane.

2. The character of the ECG's obtained points out to a considerable damage in the heart muscle.

3. Detoxication of the eel in aerated tap-water free of lindane caused return of normal ECG pattern.

\section{REFERENCES}

Belaud A., W. Peyraud and C. Peyraud 1969: Action de l'adrenaline sur l'activite electrique du coeur ferfuse de Conger (Conger conger L.). Soc. de Biol. de Rennes, 5: 163-168.

Galcstatter J. and C. Weiss 1967: The elimination of DDT, dieldrin and lindane from fish following a single sublethal exposure in aquaria. Trans. Am. Fish. Soc. 96: 301-307.

Heath A. G. 1964: Heart rate, ventilation and oxygen uptake of marine teleost in various oxygen tensions. Am.Zool. 4, 32 .

Holeton G. F. and D. J. Randall 1967: The effect of hypoxia upon the partial pressure of gases in the blood and water afferent and efferent to the gills of rainbow trout. J. Exp. Biol., 46: 317.327.

Holrngrean S., 197': regulation of the heart of a teleost (Gadus morhua) by autonomic nerves and circulating catecholaminess. Acta Physiol. Scand., 99, 1: 62-74. 
Janicki R. and W. Kinter, 1971: DDT: disturbed osmoregulatory events in the intestine of the eel (Anguille rostrata) adapted to sea water. Science, 173: 1146-1147.

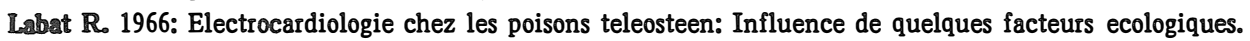
Toulouse Edouard Private, Libraire-Editeur: 255.

Leadem $T_{o}, R_{0}$ Campbell and D. Johnsen, 1974: Osmoregulatory responses to DDT and varying salinities in (Salmo jgairdneri) , 1. Gill Na-K ATPase . Comp. Biochem. Physiol., 49A, 197-205.

Nelsoa J. Aos 1982: Physiological observation on developing rainbow trout exposed to low $\mathrm{pH}$ and varied calcium ion concentrations. J. Fish. Biol., 20:359-372.

Olofifs Po, L. Albright and S. Szeto, 1972: Fate and behaviour of five chlorinated hydrocarbon in three nature waters. Can. J. Microbiol., 18, 9: 1393-1398.

Rao P. Saxi Bhushana, 1986: Effects of lindane on the ATPase activity in juvenile of Mugil cephalus linn.

J. Environ. Biol. 7, 1: 23-33.

Rollason W. Non 1966: Electrocardiography for the anaesthetist. Blackwell Scientific Publication. Oxford and Edinburgh.

Schamroth Lo, 1966: An introduction to electrocardiography. 12, 41, 83. Scientific Publication. Oxford and Edinburgh.

Schimmel So, Jo Patricls and Jo. Forester 1977: Toxicity and bioconcentration of BHC and lindane in selected estuarine animals. Arch. Environ. Contam. Toxicol. 6:355-363.

Siato T. 1973: Effects of vagal stimulation on the pacemaker action potential of carp heart. Comp. Biochem. Physiol. 44A, 1: 191-199.

Yap. Ho, D. Desaiah, Lo Cuttkomp and Ro Koch. 1975: In vitro inhibition of fish brain ATPase activity by cyclodiene insecticides and related compounds. Bull. Environ. Contam. Toxicol. 14, 2: 163-167.

\section{Mohamed Hassan Mourad}

\section{WPEYW LINDANU NA ZMIANY ELEKTROKARDIOGRAMU U WEGORZA \\ ANGULLA ANGULLA L}

\section{STRESZCZENIE}

W warunkach akwaryjnych $w$ temperaturze $18-19^{\circ} \mathrm{C}$ poddano węgorza działaniu insektycydu „Lindan” (gamma izomer hexachlorocyklohexan) rejestrując zmiany EKG $w$ odprowadzeniu pośrednim, przedsercowym, centralnym. Preparat powodował zmiany w obrazie EKG wskazujące na uszkodzenie mięśnia sercowego $z$ objawami hipoksji. Po przeniesieniu węgorzy do wody czystej EKG wracało do normy.

Author's address:

Received: 1990.09 .06

Dr. Momamed Hassan Mourad

Institute of Oceanography

and Fisheries

Alexandria, Egipt 